\title{
Judicial Conscience and Natural Rights: A Reply to Professor Jaffa
}

\author{
Bruce Ledewitz*
}

Professor Jaffa's paper represents an important step in interpreting the United States Constitution. ${ }^{1}$ Professor Jaffa demonstrates that the advocates of historical interpretation are in fact descendants of John C. Calhoun rather than of the Framers; that they consider Edmund Burke, but not Abraham Lincoln, a "Defender of the Constitution;"' and that they read God and natural rights endowed by man's creator out of the Constitution.

Professor Jaffa's critique is all the more devastating because he is himself a conservative and a historian. Because he is a conservative, the reader senses his sympathy for what Attorney General Meese, Chief Justice Rehnquist and Judge Robert Bork are attempting to accomplish. Because he is a historian, Professor Jaffa, like his predecessor in many ways, Edward Corwin, approaches the politically charged field of constitutional interpretation with the truthworthy attitude of the scholar, rather than that of the advocate.

Despite my admiration for both his undertaking and the soundness of his results, I confess an impatience with his paper. I would like to understand his critique at the point of actually interpreting the Constitution. If, as it appears at various points in his text, Professor Jaffa agrees with the votes

* B.S.F.S., 1974, Georgetown University; J.D., 1977, Yale School of Law; Professor of Law, Duquesne University School of Law. The author serves as Secretary of The National Coalition To Abolish The Death Penalty.

1. Professor Jaffa's paper does not deal with all of the problems that the original intent position, however interpreted, faces. Such questions as "who counts as a framer," "what is the relevance of the ratification process?" or even "why should intention matter in the first place?" do not occupy him here. In this paper Professor Jaffa deals primarily with a much narrower question, how well do the self-professed advocates of original intent understand the intellectual and political presumptions of the generation they accept as Framers? Surely it is justifiable to deal with an issue of manageable scale rather than to attempt to do all things at once. I will limit my reply to this same issue but from a different, one might say left-wing, perspective.

2. Jaffa, What Were the "Original Intentions" of the Framers of the Constitution of the United States, 10 U. PUGET SouND L. REv. 351 (1987) [hereinafter Jaffa]. 
cast by the Calhounites on current issues before the Supreme Court, how is it that their flawed methodology can yield reliable results? Is Dred Scott $v$. Sanford ${ }^{3}$ the last case in which a proper understanding of original intent mattered? Is slavery the last issue on which the Framers may be said to have spoken a word of liberation?

My subject is this gap in Professor Jaffa's paper between the consciousness of the Framers and the practice of judicial review today. The understanding that Professor Jaffa brings to the intent of the Framers is one that opens up the Constitution to the call of justice. Professor Jaffa's Framers are not enemies of the poor and the oppressed, the criminal defendant and the homosexual. Nor are they protectors of the rich and powerful, the washed and the comfortable.

Professor Jaffa begins with Dred Scott. ${ }^{4}$ For conservatives today, Dred Scott represents the unfortunate triumph of moralism in judicial review. Because Chief Justice Taney did not stick to the principles of original intent, but instead responded to the passions of the day, he condemned blacks as mere property, which Congress then must protect as property in the territories.

Professor Jaffa asserts that this conservative account is false. Taney was in no sense responding to the passions of the day. Taney was in fact interpreting the Constitution precisely in accordance with original intent as Meese and the others understand that concept. In analyzing the rights of black people, Taney considered the Constitution to be no more than positive law.

Here, according to Professor Jaffa, was Taney's great error and the great error of today's conservatives. Though faithful in a sense to the constitutional text and its treatment of slavery, Taney failed to deal with the "genuine principles" of the Constitution that are found in the Declaration of Independence. ${ }^{5}$ It is in the light of the equality of all men, a light bind-

3. Dred Scott v. Sanford, 60 U.S. (19 How.) 393 (1856) (Congress bound to protect slaveowner's property rights in slaves in federal territories). Dred Scott represents Professor Jaffa's starting point. See Jaffa, supra note 2.

4. Jaffa, supra note 2.

5. "[The Declaration of Independence] tells us why slavery must be regarded as an anomaly, a necessary evil entailed upon the Constitution, but not flowing from- or consistent with-its genuine principles." Id. at 364; see also id. at 408 (appendix A): "[T]he principles of the Declaration of Independence are the principles of the Constitution."

Unlike today's conservatives, Taney did not deny all authority of the Declaration 
ing on constitutional interpretation, that Dred Scott stands condemned.

Professor Jaffa's analysis of Dred Scott illustrates a fundamental ambiguity about original intent that permeates his paper. In his view, Taney did not rely on any sort of Framers' intent. In determining the Constitution's view of blacks, Taney looked to the text of the Constitution, noted its obvious acceptance of slavery and concluded from the text that blacks had no rights that the white man was bound to recognize. ${ }^{6}$ This approach may be called textual intent, and Taney's account of the text's intent is said by Professor Jaffa to be a plausible one. $^{\text {? }}$

In contrast to, or in amplification of, the method of textual intent, one might employ original intent, asking what was the intent behind the text. "Original intent" employed in this fashion might mean the views of the Framers on the issue at hand. For example, their attitude toward blacks. On the other hand, "original intent" might refer instead to the intent of the Framers generally in creating the Constitution. For purposes of this paper, I will call the first, specific intent, and the second, general intent.

Professor Jaffa is criticizing Taney for ignoring the Framers' general intent, not for ignoring the Framers' specific intent concerning the status of blacks as human beings. This criticism may at first seem odd. Taney was wrong in Dred Scott in terms of specific intent as Professor Jaffa demonstrates. ${ }^{8}$ Madison and Jefferson clearly believed blacks were human beings entitled to the inherent rights of all men. But Professor Jaffa criticizes Taney for misinterpreting the Declaration of Independence, not for ignoring the opinion of those who framed the Constitution's pro-slavery clauses. For Professor Jaffa, the Declaration of Independence is the lens through which the text of the Constitution must always be studied, however clear the text seems to be. After all, in the case of

of Independence. He asserted, however, that in light of the constitutional textual acceptance of slavery, blacks could not have been included in the commitment to the equality of all men. Taney read the Declaration in light of the Constitution, rather than the other way around. See id. at 368-69.

6. Id. at 353-54.

7. "Plausible" is far too weak a word. Although Professor Jaffa rejects the Taney interpretation, he acknowledges at length that elements of the constitutional text strongly support the Constitution's apparent pro-slavery position. Id. at 407-10 (appendix A).

8. Id. at $390-93$. 
blacks, the text was relatively clear and could be read fairly as racist. Thus Professor Jaffa is arguing for the method of general intent; he is not proposing to consult the Framers on the specific issues that come before the Supreme Court today. ${ }^{9}$

What was the Framers' general intent as revealed in the Declaration of Independence? Professor Jaffa states that the Framers' primary purpose was the creation of a government that would "secure" certain rights. ${ }^{10}$ Indeed, "to secure these rights" was viewed by the Framers as the sole legitimate purpose of any government. ${ }^{11}$ The Framers were attempting to establish in positive law, "[t]he primacy of rights and of right, understood in the light of the laws of nature ...."12 Professor Jaffa describes these rights: "These rights were the unalienable rights with which all men had been equally 'endowed by their Creator' under 'the laws of nature and of nature's God."13 Certain of these rights are denominated in the Declaration of Independence: "Life, Liberty and the Pursuit of Happiness." For Professor Jaffa the Declaration is not merely a precatory document to be trotted out for Fourth of July speeches. Rather, he calls the Declaration "the most fundamental dimension of the law of the Constitution."14

Professor Jaffa's major example, Dred Scott, illustrates the role that he thinks general intent should play in interpreting the Constitution. The Declaration's assumption of basic human equality represents the Constitution's "genuine" principle on the issue of slavery. The doctrine of the inequality of blacks, strongly supported by hints in the constitutional text, should be considered a mere compromise with transient political forces.

Professor Jaffa's main purpose is to show that neither today's conservatives nor today's liberals understand and follow original intent. The conservatives who claim to embody original intent do not understand "what . . . original intent was." 15 They are "antagonists" of original intent ${ }^{16}$ because,

9. "In asking what were the original intentions of the founding fathers, we are asking what principles of moral and political philosophy guided them. We are not asking their personal judgments upon contingent matters." Id. at 386.

10. Id. at 355 .

11. Id. at 378 .

12. Id. at 384 .

13. Id. at $355-56$.

14. Id. at 363 .

15. Id. at 354 .

16. Id. at 356. 
like the apologists for slavery of an earlier time, they "rejected the ground of the Constitution in natural justice. . .."17

At much less length, Professor Jaffa criticizes liberal jurisprudence on precisely the same ground, that liberals reject "natural rights teaching."18 Because the individual has no inherent rights that the majority is bound to respect, liberals seeking to enhance liberty must refer to an evolving conscience of a future, reformed "scientific" society."19 Conservatives and liberals, thus, "stand upon common ground."20 That ground turns out, jurisprudentially, to be a positivist vision of law that grounds authority in the will of the people, either today's will or that of tomorrow.

What are the implications of this powerful critique? What sort of jurisprudence would result from a modern commitment to the natural law principles of the Declaration of Independence?

Professor Jaffa does not expressly venture onto this ground. Unfortunately, his implied prescription for conservatives is to accept an antiquated natural rights outlook, and for liberals, to abandon the search for a modern one.

To see the first point, imagine Professor Jaffa addressing Chief Justice Rehnquist, the "pure legal positivist." 21 Chief Justice Rehnquist would assert that there are no "self-evident truths," that there is no accessibility to a divine intention for humankind, and, thus, no endowed rights. ${ }^{22}$ Or at least Chief

17. Id. at 362 .

18. Id. at 394 .

19. Id. at 394-95; see also id. at 355-56.

20. Id. at 395 .

21. Id. at 393.

22. This is my conclusion from reading Chief Justice Rehnquist's more ambitious attempts to declare a theoretical approach to constitutional interpretation. See Rehnquist, Government by Cliche: Keynote Address of the Earl F. Nelson Lecture Series, 45 Mo. L. REv. 379 (1980) [hereinafter Government by Cliche]. As I discuss infra note 23, Professor Jaffa views my statement in the text here, as well as similar expressions of mine elsewhere, as overstatements of what Chief Justice Rehnquist has actually said. Thus, although I have not changed my view, I add the next statement in the text as a toned-down alternative. I would urge the interested reader, and since this man is now Chief Justice of the United States it behooves us all to be interested, to read the two articles herein cited. I find revealing, in particular, Chief Justice Rehnquist's argument in The Notion of a Living Constitution, 54 TEx. L. REV. 693, 704-05 (1976), that all moral judgments are only "personal" and "individual" until enacted into law, and his argument in Government by Cliche, $45 \mathrm{Mo}$. L. REv. at 390392 , that the authority of the Constitution is grounded in majority rule rather than in "any principles of rational law." These expressions are entirely inconsistent with the ideas of self-evident truth and endowed rights. I know it sounds strange to criticize a 


\section{Justice Rehnquist would say that if people disagree about these matters, discussion must be closed. At the point of disagree- ment, there is nothing more than subjective preference, which may or may not be backed by power. ${ }^{23}$}

Justice for being an atheist when we usually regard such matters as personal. But I do not mean that Chief Justice Rehnquist attends no chuch, which I do not know and which is none of my business, but rather that he is a jurisprudential atheist, a man for whom law is grounded in nothing more than the power of the majority. These matters are discussed in great depth in Professor Jaffa's appendix C, supra note 2, at 422.

23. Professor Jaffa is kind enough to include in his critique of Chief Justice Rehnquist in appendix $\mathrm{C}$ several references to a short article I wrote in the Wall Street Journal, Aug. 7, 1986, at 20, col. 3. I would say that Professor Jaffa states my criticism of Chief Justice Rehnquist far better than I could, and did, myself.

Professor Jaffa errs, however, in criticizing my characterization of Chief Justice Rehnquist as one "who does not believe there is such a thing as right and wrong." Professor Jaffa argues that what Chief Justice Rehnquist says is that right and wrong cannot be logically demonstrated, not that they do not exist, and thus like Carl Becker, Chief Justice Rehnquist may nevertheless believe in the right as a fundamental reality. The difference between the two cases is that Carl Becker's belief justified action, in his case a willingness to kill or be killed. In the case of Chief Justice Rehnquist, the unavailability of logic to resolve issues of value is an argument for a judge not to act. This unwillingness to act suggests that Chief Justice Rehnquist does not accept the difference between right and wrong as representing a fundamental reality.

For Chief Justice Rehnquist, the world is divided between facts and opinions. Facts are amenable to empirical or logical verification. Opinions are subject to no sort of verification. When I called Chief Justice Rehnquist's commitment to an objective analysis of original intent "unobtainable," I had in mind these categories of empirical or logical verification. Obviously, the views of Madison and Jefferson are subject neither to empirical nor logical verification. One must look at the evidence and make reasoned argument. But, of course, one can proceed in the same way; that is by argument rather than verification when discussing fundamental values, which, Chief Justice Rehnquist says, is the reason for banishing such talk from the courtroom.

It should be noted that Professor Jaffa's category of reason at times seems to go a great deal beyond Chief Justice Rehnquist's idea of how an argument can be justified. Reason for Professor Jaffa is not always limited to empiricism and logic, but partakes of all the different aspects of human understanding. This approach to reason seems to parallel Edmond Cahn's description of the sense of injustice: "a blend of reason and empathy." See Ledewitz, Edmond Cahn's Sense of Injustice: A Contemporary Reintroduction, 3 J. LAW \& REL. 277, 285 (1985) [hereinafter cited as Cahn]. At other times, however, Professor Jaffa treats reason as merely empirical or logical. Consider Professor Jaffa's assertion that a black person's humanity "is a matter of fact and not of opinion. Jaffa, supra note 2, at 446 (appendix C). That it is, but not because the slave codes inconsistently treated blacks. For even if the slave codes had consistently degraded blacks, blacks would still have retained their humanity. To put this another way, the humanity of blacks is a "fact" more fundamental then either empirical or logical demonstrations. Professor Jaffa faults Carl Becker for acknowledging this, but what arguments could "objectively prove" the humanity of a person? The category of the real is objectively true, but may not be amenable to the sort of demonstration Professor Jaffa sometimes suggests reason can provide. Compare Edmond Cahn's comment about slavery, that it "was doomed to disappear everywhere, for no other reason than that a slave is a man." E. CAHN, THE SENSE OF INJUSTICE: AN ANTHROPOCENTRIC VIEW OF LAW 15 (1949). Even though Cahn did not share Professor 
Professor Jaffa associates the Framers with a different view of the universe. According to this view, political science and law are capable of uncovering a "true understanding"24 of the individual and her relation to society. There are principles, "truths 'applicable to all men and all times," "25 that Chief Justice Rehnquist must accept if he wishes to interpret the constitution in accordance with original intent.

It is not clear how Professor Jaffa would like Chief Justice Rehnquist to respond to his position. If the Chief Justice examines modern philosophy, history, anthropology and, yes, even science, as well as his own being and concludes that this claim about eternal truth is incoherent, an echo of a less sophisticated time, he can hardly will himself to believe otherwise. Professor Jaffa obviously agrees with the Framers that their views are self-evident. But Professor Jaffa knows he is addressing an audience in which no one else is persuaded. ${ }^{26}$

This is precisely the dilemma John Hart Ely brilliantly described in Democracy and Distrust. ${ }^{27}$ In assessing a hypothetical natural law jurisprudence, Ely asked what we would do with a constitutional provision protecting ghosts. How could we who know that there are no such things attempt to interpret the Constitution as if we did believe in ghosts and apply the implications of ghost-belief? Such an undertaking would be self-defeating. Because we do not believe in ghosts, an appropriate application of a ghost provision would be beyond us.

Chief Justice Rehnquist, who does not believe in the ghost of natural law, seems to have two intellectually honest options if he were to accept Professor Jaffa's account of the Framers' views. One option would be to abandon original intent altogether and to find some other basis to interpret the Constitution. Chief Justice Rehnquist would reject this approach because in his view only original intent is a ground beyond subjective judicial will. The second option, the one the Chief Jus-

Jaffa's confidence in reason alone, he did not abandon the true. Nor did he abandon reasoning about the true.

24. Jaffa, supra note 2, at 425 (appendix C).

25. Id. at 374 .

26. "The crisis of American constitutionalism-the crisis of the West-lies precisely in the denial that there are any such principles or truths. It is no less a crisis in the heart of American conservatism than of American liberalism." See id. at 386. See generally id. at 415-22 (appendix B).

27. J. ELY, DEMOCRACY AND DisTruST 38-40 (1980) [hereinafter ELy]. 
tice usually attempts to utilize, ${ }^{28}$ is to find in history the Framers' views, their "personal judgments upon contingent matters," on a particular issue before the Supreme Court. ${ }^{29}$ The advantage of this approach is that such specific intent is sometimes reasonably ascertainable and thus serves to limit the judiciary's otherwise plenary power to rule at will.

Professor Jaffa's paper demonstrates that the second option is an illusion because specific intent is not true to the Framers' larger purposes. In that sense, it is not an original intent methodology at all. Thus, even if Chief Justice Rehnquist could establish, for example, that the Framers thought Congress possessed the authority to proscribe abortions, the Supreme Court should not enforce specific judgment if, under today's circumstances, to do so would violate the Framers' understanding of equality and liberty. We must understand "what principles of moral and political philosophy guided" the Framers ${ }^{30}$ before we make legal judgments in which the constitutional text is silent or ambiguous. Furthermore, Chief Justice Rehnquist's underlying and implied idea, that if there is no clear textual prohibition, government may act, is an excellent illustration that specific intent without a larger framework is dangerous. The Framers did not assume that, generally, government could act. They assumed the converse that, generally, individuals could act. Thus, there is no genuine constitutional presumption against judicial action when the constitutional text is not a clear guide.

Professor Jaffa does not argue for such specific intent. Nor, of course, is he proposing to abandon original intent. Professor Jaffa wants conservatives to subscribe to the "true" understanding of original intent ${ }^{31}$ both because this is a legitimate method of interpretation and, more important, because the Framers' views of man and majority are themselves eternally true.

But what sense does this call for a return to the "true" understanding of original intent make when addressed to people who, in good faith, find original intent to be gibberish? Here we would expect Professor Jaffa to show that the Framers' views are true and that modern critics of natural rights are

28. I describe briefly Chief Justice Rehnquist's reliance on specific intent, which I call the "historical method" in Cahn, supra note 23, at 314-19 n.163.

29. Jaffa, supra note 2 , at 386.

30. Id.

31. Id. at 425 (appendix C). 
wrong. He avoids this effort, however. Perhaps he feels that, as a historian, it is not his place. Or perhaps, he imagines that once conservatives understand "what the original intent was," they will come to believe it. This is a forlorn hope.

What Professor Jaffa seems to urge, instead, is that judges rely upon the Declaration of Independence whether they believe in self-evident truths or not. It is clear that the Framers were committed to equality, life, liberty, and property. It is also clear that the Framers presumed that individual preferences in these realms would govern even against the pronouncements of majoritarian governments. If we cannot believe what they believed, we can at least follow loyally where the Framers led.

This approach, to act as if we believed, turns today's conservatives into a generation of atheists carrying forward a tradition of theism. And it turns the truths of the Declaration into principles we decide to accept as if true. What do such pretenders do, however, with disputes about the implications of equality, liberty, and property? Professor Jaffa provides no answer to this crucial question. But judging from Professor Jaffa's criticism of judicial activism and legislation, ${ }^{32}$ his determination to avoid any new applications of the Declaration of Independence, it is obvious that we are to find answers in Aristotle and Cicero, and if not in them directly, in them as interpreted by the Framers' generation.

Professor Jaffa demonstrates this tendency in his reference to racial quotas in appendix $A .^{33}$ Attorney General Meese asserts that racial quotas are unconstitutional as a violation of equality. With this Professor Jaffa agrees. But we know this, asserts Professor Jaffa, only from the perspective of "the Declaration's understanding of equality."34

I assume that the "Declaration's understanding" means simply the views of Madison and Jefferson, or of their teachers Aristotle and Cicero, regarding the meaning and portent of equality. But this historical approach treats the Declaration as a document frozen in time. The authority of the Declaration's assertions cannot be based on age, but on their truth. But if truth is the ground of their authority, we cannot avoid asking ourselves what is the nature of the equality we may all justly

32. See, e.g., id. at 356, and 357-59.

33. Id. at 402-04 (appendix A).

34. Id. at 405 (appendix A). 
claim from birth and what are its consequences. That is, we must ask this question of ourselves and not just of Aristotle, Cicero, Madison, and Jefferson. I have no love for quotas, but real questions of moral right and political policy cannot be handled by quotes from the ancients about abstractions like equality.

Self-conscious emulation is not natural law. Nor is it true to the Framers' intent. It is an archaeological dig into the remnants of natural law. It is an attempt to hold human understanding still at a certain point in time. Neither a judge nor a legal thinker can be true to the tradition of natural law unless it lives in her. Merely to appeal to equality without commitment to the reality of equality, its self-evident quality, is to celebrate the shell without the substance. And the results that such an antiquated method purports to yield cannot do justice to the living tradition that the Declaration of Independence celebrated. It is not that Aristotle is not to be consulted; it is rather that we have seen and experienced some truth since then. It is dangerous to attempt to apply the insights of old literally.

But Professor Jaffa discourages any contemporary attempt to live within the principles of the Declaration of Independence. He is wedded to antiquity. The problem for Professor Jaffa is that he wishes to be true to an original intent that is revolutionary in its call for natural justice, but also wants to restrict carefully the implications of original intent.

Professor Jaffa takes pains to insulate himself from what he calls judicial activism. His methods of limitation are first, fidelity to the text; second, opposition to judicial "evolutionary conscience"; and third, the requirement of corporate judicial action. For those who consider the principles of the Declaration of Independence to be true, these negative techniques interfere with an attempt to practice the constitutional tradition bequeathed to us by the Framers.

Professor Jaffa makes the textual point in a discussion of Justice Brennan's opposition to the death penalty. Justice Brennan's Constitution is said by Professor Jaffa to represent principles without a text that ignores the fifth amendment's clear acknowledgment of capital punishment. If we take original intent as seriously for issues today as Professor Jaffa does for slavery, we see that the Constitution does not support capital punishment. 
According to Professor Jaffa, though the Constitution promotes slavery in several respects, it is not a pro-slavery document. Slavery is a prudent compromise, not a matter of genuine constitutional principles. The genuine principle is said to be human equality as demonstrated by the Declaration of Independence.

But the Declaration of Independence also proclaims the unalienable right of human persons to "life." One may say that the calculated taking of human life is presumptively disfavored under the Declaration of Independence, just as slavery clearly is disfavored.

The fifth amendment ${ }^{35}$ no more turns the Constitution into a pro-death penalty document than the fugitive slave provision turns the Constitution into a pro-slavery document. The fifth amendment represents a limitation on capital punishment, that it was not to be carried out in the future as it had been in the past. One could hardly call the due process clause an endorsement of capital punishment. It acknowledges that capital punishment was a prevailing practice, but this recognition is similar to the recognition accorded slavery. The genuine principle of the Constitution is "life," just as surely as it is "equality."

In fact, the attack on capital punishment through the eighth amendment is much more consistent with the text of the Constitution than is Professor Jaffa's attack on slavery. The constitutional text seems actually to endorse slavery. Conversely, the eighth amendment was viewed at the time of its introduction and criticized as an invitation to abolish capital punishment. ${ }^{36}$ Reading the reference to deprivation of life in the fifth amendment as if it had been intended to quiet the fear of abolition is more weight than this reforming provision will bear. The due process clause is more easily interpreted as quieting the opposite fear: that the death penalty would be widespread and discretionary if the eighth amendment were not interpreted to eliminate it. To exclude the due process

35. "[N]or shall any prisoner be subject for the same offense to be twice put in jeopardy of life or limb... nor be deprived of life, liberty, or property, without due process of law." U.S. CONST. amend. VIII.

36. This is the gist of the celebrated objection of Representative Livemore of New Hampshire during consideration of the proposed eighth amendment: "[I]t is sometimes necessary to hang a man, villains often deserve whipping, and perhaps having their ears cut off; but are we in the future to be prevented from inflicting these punishments because they are cruel?"' 1 ANNALS OF CONG. 754 (J. Gales ed. 1789). 
clause might have suggested that a citizen could be deprived of life without due process.

I do not mean to argue literally that the death penalty and slavery issues are the same. We know on good authority that many of the Framers did oppose slavery, but agreed to its inclusion in the Constitution as the cost of union. There is no reason to think the Framers similarly opposed capital punishment, but refrained from condemning it as an act of compromise. But the Framers' personal views on the death penalty should not matter. Professor Jaffa does not rely primarily on the Framer's personal opinions. He relies instead on the public principles of the Declaration of Independence. Professor Jaffa would say that even if many of the Framers supported slavery (and of course some did, thus requiring compromise), the Declaration of Independence would still condemn it because the Declaration proclaims equality. Similarly, even if the Framers supported the death penalty, which I do not know to be true, the Declaration would still condemn it, for it proclaims the right to life.

Professor Jaffa's textual attack on the abolition of the death penalty is particularly unpersuasive given the Framers' view that a bill of rights was unnecessary. ${ }^{37}$ The Bill of Rights was introduced only later to respond to fear of an oppressive federal government. But that must mean that the federal government was barred from violating the principles later embodied in the Bill of Rights even without these express limitations. Such a view would have supposed that article I did not authorize the federal government to act oppressively or, more generally, that no government could legitimately claim the right to oppress its own people, notwithstanding prevailing doctrines of parliamentary supremacy.

To translate these generalities into a modern context, a German judge in the 1930's or a South African judge today would be entitled, under the Framers' view of legitimate authority, to condemn oppression by their governments whether positive law sanctioned judicial review or not. That is, governments may claim only powers consistent with inherent rights. Since the individual citizen would not, or could not,

37. Consider the comment of Alexander Hamilton in the 84th FEDERALIST: "I go further, and affirm that bills of rights . . . are not only unnecessary in the proposed Constitution, but would even be dangerous. They would contain various exceptions to powers not granted. . . F For why declare that things shall not be done which there is no power to do?" THE Federalist No. 84, at 537 (A. Hamilton) (H. Lodge ed. 1888). 
have ceded ${ }^{38}$ the power of tyranny to his government, tyranny is never legitimate. ${ }^{39}$

This is a jurisprudence of liberation, if ever one existed. But we find its expositor, Professor Jaffa, suggesting that a judge in America, where the Framers' views have the authority of positive law as well as inherent right, may not rely on the principles of the ends of legitimate government, but must stay within the text of the Bill of Rights. The Bill of Rights is not a limit on individual liberty. Chief Justice Rehnquist may believe that government may lawfully do anything not prohibited by the Bill of Rights. But Professor Jaffa knows that this was not the Framers' intention. Their intention was to specify some of the limits on government, but not all of them. And this intention was written specifically into the text of the ninth amendment. ${ }^{40}$ Where should the judge look to see what the rest of the limits on government power are? The judge need look no further than the principles of the Declaration of Independence.

A second aspect of Professor Jaffa's resistance to judicial activism is his attack on "evolutionary conscience"41 in legal thinking. Professor Jaffa accuses liberal jurisprudence of dismissing the insights of the Framers in the name of new insights said to be based on science.

The heart of this critique is valid. The Framers proposed eternal principles based on an unchanging human nature created by God. Liberal and radical left-wing legal thinkers today reject all such conceptions as epistemologically naive. This is as true of main line consensus thinkers like Owen Fiss, ${ }^{42}$ and Harry Wellington, ${ }^{43}$ as it is of the Conference on Critical Legal Studies. ${ }^{44}$

38. Professor Jaffa does not attribute to the Framers a social contract into which one might actually enter. As the Virginia Declaration of Rights put it, people "cannot" divest their posterity of inherent rights. Jaffa, supra note 2 , at 385.

39. I should add here a reference to the brave Ghanian judges whose insistence upon the availability of habeas corpus, despite a military constitution that apparently precluded judicial review, ultimately proved fatal to several of them. Cover, The Supreme Court, 1982 Term-Forward: Nomos and Narrative, 97 HARV. L. REv. 4, 59 (1983).

40. "The enumeration in the Constitution, of certain rights, shall not be construed to deny or disparage others retained by the people." U.S. CONST. amend. IX.

41. Jaffa, supra note 2 , at 385 .

42. See O. Fiss, Objectivity and Interpretation, 34 STAN. L. REV. 739 (1982).

43. See Wellington, Common Law Rules and Constitutional Double Standards: Some Notes on Adjudication, 83 Y ALE L.J. 221 (1973).

44. See, e.g., Singer, The Player and the Cards: Nihilism and Legal Theory, 94 
Although this criticism may be valid with regard to those who do not accept the Framers' fundamental notions of enduring standards of right and wrong, what of those who share the Framers' commitments? Are they condemned never to learn anything from science or other advances in human thinking?

Consider the issue of protecting developing fetuses under the fifth and fourteenth amendment. The long term significance of this issue is that when and if Roe $v$. Wade $e^{45}$ is overruled, a period of state choice with regard to abortion laws will be ushered in unless due process and equal protection are read to require protection of the unborn.

The prevailing view on the Court, in fact the only view expressed in Roe v. Wade, is that fetuses are not "persons" for purposes of the fourteenth amendment and so are not protected. Justice Blackmun's majority opinion utilized the specific intent technique Judge Bork has used to illustrate an argument against the availability of equal protection for gay people. ${ }^{46}$ Justice Blackmun argued that the Framers of the fourteenth amendment were not considering fetuses when they wrote the word "person." 47

This is the sort of simplistic original intent analysis that Professor Jaffa has in mind when he says that we are not bound by the specific judgments of the Framers on contingent matters. ${ }^{48}$ I doubt that the Framers of the fifth amendment or

YALE L.J. 1 (1984). I am not suggesting that Joseph Singer's comprehensive statement is representative of Critical Legal Studies thinking in all ways; but insofar as he rejects the Framers' worldview, he is quite representative.

45. 410 U.S. 113 (1973) (Roe invalidated state laws prohibiting abortion during the first six months of pregnancy).

46. Bork, The Constitution, Original Intent, and Economic Rights, 23 SAN DIEGO L. REv. 823, 828 (1986) [hereinafter Bork].

Assume for the sake of the argument that a judge's study of the evidence shows that both black and general racial equality were clearly intended, but that equality on matters such as sexual orientation was not under discussion.

.... [The judge] has, therefore, no warrant to displace a legislative choice that prohibits certain forms of sexual behavior.

I am never sure how literally specific intent proponents intend to be taken. Judge Bork uses the example of sexual orientation to illustrate a group whose rights were "not under discussion." But gays are a politically easy target who have achieved little protection in any event under the fourteenth amendment. Would Judge Bork launch the same wholesale attack against any judicial protection of the equal rights of women? Surely sexual equality "was not under discussion" when the fourteenth amendment was adopted.

47. 410 U.S. at 156-59.

48. Jaffa, supra note 2 , at 386 . 
the fourteenth amendment thought about the rights of the fetus.

Even Professor Jaffa's “true understanding" of the Framers' original intent is little help in evaluating the rights of the fetus. Acknowledgment of individual rights does not tell us whether the fetus is to be recognized as such an individual, as a member of the human family. I admit that the analysis Professor Jaffa attributes to Lincoln concerning whether blacks are human beings seems to me so unerringly applicable to the unborn that it is disconcerting to read (if blacks are not human beings, may masters then eat them?). ${ }^{49}$ Nevertheless, given the nature of the question, original intent is a very uncertain guide concerning the unborn.

But science teaches us a great deal. Every act of fetal surgery, every early intervention to improve the health of the developing child, every sonogram proudly displayed by new parents, in short, all that modern science teaches us about developmental biology proclaims the fetus to be our young brother or sister in the human family. And once we know this, we cannot forget it for purposes of a legal argument. These insights do not resolve the abortion dilemma. In fact, they reveal it for the dilemma it is. ${ }^{50}$ But the insights of science are as entitled to a hearing as any other claim to truth.

Nor is new learning limited to physical sciences beyond the grasp of the Framers. New learning extends to new insights into older practices with which the Framers were familiar. A good example is the view of the Framers that private property is the "product of a man's labor." 51 It is no secret that high on the political/legal agenda of the Neo-Locke-

49. Id. at $446-48$ (appendix C).

50. Professor Jaffa desires the "prudential" morality of the Framers. "But knowing that [slavery] is wrong does not, of itself, tell us what to do about it." Id. at 371. The situation with regard to abortion is similar. Although the unborn child is always an innocent victim, even in the cases of rape and incest, it is unthinkable to me that anyone would consider forcing a woman to live with that experience by bringing the pregnancy to term. Even in the so-called "easier" cases of a woman's emotional or financial incapacity, it is relevant to consider the burden society is content to visit on young mothers. By social convention and the resulting laziness of law, society encourages sexual exploits by young men by force or seduction, dependence by women, and irresponsibility as to birth control. Then, after the baby is born, society allows the father to remove himself both physically and financially so that essentially all of the burdens of parenthood remain with the mother. If abortion is to be a crime, one must act with full awareness of society's callousness about young life once it is brought into the world.

51. Id. at 380 . 
ans, Stephen Macedo, Richard Epstein, the Cato Institute and all the rest, is an attack on the New Deal and the Welfare State in the name of the Framers' commitment to individual property rights. ${ }^{52}$ Since every man is entitled to the fruits of his own labor, progressive taxation, income redistribution and governmental regulation all become disfavored, if not unconstitutional. But Marxism, as well as the lessons of an interconnected industrial society, should have taught us something about the role of property. Property is never a matter of individual right alone. Property is a social product. This knowledge shapes our understanding of natural rights.

While one may say this is a matter of evolutionary conscience, it reflects simple growth of human understanding. But it does not follow that the starting point of inherent rights grounded in human nature and nature's God is thereby lost.

What did the Framers bequeath to us in the Declaration of Independence? Self-evident truth. The equality of mankind. Certain rights that flow from these insights. It should come as no surprise that people in a later age still committed to selfevident truth and the equality of humankind might think differently about the rights that are thus implied. This bothers Professor Jaffa, but I wonder whether Madison and Jefferson would have objected.

It is important to Professor Jaffa that the Framers' insights be permanent. ${ }^{53}$ And they are. Man's creatureliness, his place in the world as one who seeks his purpose, is not subject to change. The equality of persons, the claim of each of us to be recognized as supremely important, is not subject to change. The inherent rights of man, that there are limits to what any individual or majority may rightly do to a fellow human being, are not subject to change. But the particular con-

52. Stephen Macedo's excellent monograph brings much of this together. S. Macedo, THE NEW Right v. THE Constitution (1986). Fittingly, the monograph is published by the Cato Institute with an introduction by Richard Epstein. Macedo argues a theory of original intent very close to that of Professor Jaffa and criticizes the skepticism of Judge Bork and Attorney General Meese on much the same grounds as does Professor Jaffa. Unlike Professor Jaffa, however, Macedo raises the issue of protection of property from government interference. Of course, Professor Epstein has done so with even more vigor. See R. EPSTEIN, TAkINGS: PRIVATE PRoperty AND THE POWER OF EMINENT DOMAIN (1985).

53. "Historical experience means experience in time, but what is permanent is recognized as an intelligible necessity-or as grounded in an intelligible necessityoutside of time." Jaffa, supra note 2, at 385-86. 
tent as well as the application are subject to change. They have to be if the constitutional tradition is to live.

Does this level of abstraction distort the Framers? ${ }^{54}$ I suppose in a way it does. To be true to the Framers' view of reality, we must reject some of the implications they drew from man's equal endowment of rights.

But it is Professor Jaffa's third criticism, that Justice Brennan is willing to act alone in his interpretation of the Constitution, that seems the furthest removed from his explanation of the Framers' original intent. In repeating the textualism point made above, Professor Jaffa adds the following:

Thus Justice Brennan finds the true meaning of the Constitution, not in the text and not in any interpretation of the text by others, including the entire political community acting through the political process, but in some kind of 'striving', albeit 'not yet arrived.' This 'striving' may have the character of a revelation vouchsafed to the Justice, but not to anyone else. ${ }^{55}$

What sort of method does Professor Jaffa think is the appeal to "self-evident" truths if not "revelation vouchsafed" to certain people, in particular, to the Framers? In 1776, most of humankind did not agree that "all men are created equal." Professor Jaffa points out that the South later made precisely the opposite claim. ${ }^{56}$ There is no appeal to "others" that can decide the matter of the equality of all men, for it was and is a matter of dispute. If, however, one sees the self-evidence of the statement "all men are created equal," those proclaiming inequality must be viewed as deluded. John Hart Ely makes wonderful fun of the idea that those who disagree with one person's view of natural law are denounced as wrong. ${ }^{57} \mathrm{He}$ is right that it is an indefensible embarrassment. Nevertheless, show me a Nazi laughing at man's essential equality, and I say the Nazi is either crazy or is denying the evidence of his own

54. Compare Judge Bork's criticism of distorting the Framers' specific intent by over-abstraction. Bork, supra note 46 , at $827-28$.

55. Jaffa, supra note 2 , at 357 .

56. Id. at 392-94.

57. ELY, supra note 27, at 48: "Well, what may seem like the truth to you," said the seventeen-year-old bus driver and part-time philosopher, "may not, of course, seem like the truth to the other fella, you know."

"THEN THE OTHER FELLOW IS WRONG, IDIOT!" (quoting P. ROTH, THE Great AMERICAN NOVEL 20 (1973)). 
being. All natural law, as the Framers understood, rests on some such appeal to self-evident principles. This represents one of the great weaknesses of natural law. But that does not mean natural law is untrue.

Perhaps Justice Brennan is not committed to original intent. ${ }^{58}$ Accordingly, Justice Brennan's search for an evolving consensus may in fact be subject to Professor Jaffa's criticism that it represents arrogant subjectivity. But for Professor Jaffa to criticize generally the idea of individual access to truth is an appalling irony. Professor Jaffa believes and is totally committed to the proposition that all men are endowed by their Creator with certain unalienable rights. Now how did this idea come to Professor Jaffa? Certainly, as he admits, the elites of our time do not believe it. Philosophers reject it. Liberal and conservative jurisprudence reject it. It may be that most Americans still believe in inherent rights, but that traditional belief may be fading under the pressure of positivism and modernity. ${ }^{59}$ If the day should come that no one else takes the idea seriously that man has inherent rights given by God, would Professor Jaffa then abandon it? No. Because it is true. Why then should a Justice of the Supreme Court interpreting fundamental rights be subject to a numbers test?

The Supreme Court has not shied away from judgments based on personal moral insight. Despite some energetic dissents, the Court has condemned conduct that shocks the judicial conscience or violates some similar formula. ${ }^{60}$ Even

58. I am sorry that Professor Jaffa makes so much of an isolated quotation from Justice Brennan's speech in The Great Debate: Interpreting Our Written Constitution, THE FEDERALIST SOCIETY 11-25 (1986). Considering the speech as a whole, as well as Justice Brennan's recent comments in the Harvard Law Review, Brennan, Constitutional Adjudication and the Death Penalty: A View From the Court, 100 HARV. L. REV. 313 (1986), and, of course, his concurrence in Furman v. Georgia, 408 U.S. 238, 257 (1972) (Brennan, J. concurring), I am not sure that Professor Jaffa has accurately interpreted Justice Brennan's method. This matter is beyond my scope here, I am content to deal with these isolated passages as given.

59. Professor Jaffa in fact complains that "professional philosophers" have "mined and sapped the ordinary man's confidence in the vitality of ordinary language, and of common sense moral judgments. ..." Jaffa, supra note 2, at 416.

60. See generally Miller v. Fenton, 106 S. Ct. 445, 449 (1985): "This Court has long held that certain interrogation techniques, either in isolation or as applied to the unique characteristics of a particular suspect, are so offensive to a civilized system of justice that they must be condemned under the Due Process Clause of the Fourteenth Amendment." The classic cases are Rochin v. California, 342 U.S. 165, 172-73 (1952) ("conduct that shocks the conscience" or "afford[s] brutality the cloak of law") and Brown v. Mississippi, 297 U.S. 278, 286 (1936) ("revolting to the sense of justice"). In more recent cases, Court majorities have not used this express language and it has 
Justice O'Connor, a member of the conservative bloc on the Court, has spoken in this idiom. ${ }^{61}$

When the Court does this, as when, for example, the Court condemns the use of the stomach pump in Rochin, ${ }^{62}$ it is without regard to interpretations of the constitutional text by others. It is, in fact, with only the vaguest nod toward the text at all. And no nod at all to the political community. The Court was not concerned in Rochin with what others thought; such conduct is condemned by any civilized conscience.

Many of our greatest cases rely on such moral insights by the Court. Brown $v$. Board of Education's ${ }^{63}$ condemnation of segregation laws can be defended, if one is interested in doing so, by its stabs at history and by the words "equal protection" in the constitutional text. But Professor Jaffa is on sounder ground in asserting that segregation laws were "utterly inconsistent with the ends of free government and hence of the Constitution."64 Professor Jaffa's implication is that any practice "utterly inconsistent with the ends of the free government" violates the Constitution. And he is right. The Court certainly agreed with this implication when it held that the federal government was also precluded from segregating blacks, despite

remained for dissents, often by Justice Black, to point out the underlying premise of the majority holding. See, e.g., Boddie v. Connecticut, 401 U.S. 371 (1971) (Black, J., dissenting). "The Equal Protection Clause is no more appropriate a vehicle for the 'shock the conscience' test than is the Due Process Clause," $i d$. at 394; and Harper v. Virginia Board of Elections, 383 U.S. 663, 675-680 (1966) (Black, J., dissenting) (criticism of "natural-law-due-process formula"). To its great credit, the Court prevented the State of Texas from denying public schooling to the children of illegal aliens under this natural law tradition. Plyler v. Doe, 457 U.S. 202 (1982): "Even if the State found it expedient to control the conduct of adults by acting against their children, legislation directing the onus of a parent's misconduct against his children does not comport with fundamental conceptions of justice." Id. at 220 . It is important to note that even when refusing to apply the "shock-the-conscience" test, the Court has never abandoned it. See, e.g., Moran v. Burbine, 106 S. Ct. 1135, 1147 (1986) and Louisiana v. Resweber, 329 U.S. (1947).

61. 329 U.S. 459, 473 (1947) (Burton, J., dissenting).

We do not question that on facts more egregious than those presented here police deception might rise to a level of a due process violation. . . . We hold only that, on these facts, the challenged conduct falls short of the kind of misbehavior that so shocks the sensibilities of civilized society as to warrant a federal intrusion into the criminal processes of the States. Id.

62. Rochin v. California, 342 U.S. 165 (1952) (after the defendant swallowed two capsules containing morphine, the police directed a doctor to force an emetic solution through a tube into the defendant's stomach. Resulting evidence was excluded.)

63. 347 U.S. 483 (1954).

64. Jaffa, supra note 2 , at 403 . 
the absence of both history and text condemning the practice in the fifth amendment. ${ }^{65}$ The Justices simply could not stomach the scandal of federal segregation any longer. ${ }^{66}$

I cannot believe that Professor Jaffa lacks sympathy for a judge confronting a fundamental injustice. He does not condemn Griswold, ${ }^{67}$ and I doubt he would condemn Skinner. ${ }^{68}$ Furthermore, the refusal of the Justices to countenance oppression is fully in keeping with the spirit of inherent rights that Professor Jaffa celebrates and that the ninth amendment embodies. Without any textual support at all, governments have never possessed authority to segregate or otherwise to oppress their citizens. Why then is Professor Jaffa so certain that governments have been given authority to kill their prisoners through capital punishment? While I acknowledge that opinions differ, it is clear to me that killing a citizen in a prison cell is utterly inconsistent with the ends of free government. And if, upon reflection and moral insight, a Justice is convinced of this truth, the Justice has an obligation to act-even if alone.

Of course, setting oneself up as spokesman for truth against the judgment of the majority of one's fellows is no small thing. But thinkers about the Constitution should not overemphasize the danger. Certainly this context was not unfamiliar to the Framers. They knew that majorities were capable of despotism. I do not doubt, for example, that a large majority would agree today to modest torture for certain murderers, except that we are restrained by the eighth amendment. If the eighth amendment were removed, Chief Justice Rehnquist believes this protection would vanish. ${ }^{69}$ But this

65. Bolling v. Sharpe, 347 U.S. 497 (1954).

66. Id. at 500: "In view of our decision that the Constitution prohibits the states from maintaining racially segregated public schools, it would be unthinkable that the same Constitution would impose a lesser duty in the Federal Government." Id.

67. Griswold v. Connecticut, 381 U.S. 479 (1968) (conviction for giving birth control instruction to married couple reversed). Griswold is discussed by Professor Jaffa with at least an air of sympathy in Jaffa, supra note 2, at 402-04 (appendix A).

68. Skinner v. Oklahoma, 316 U.S. 535 (1982) (Equal Protection bars sterilization for persons convicted two or more times of felonies involving moral turpitude). Skinner is generally regarded as a substantive due process case disguised as equal protection. See Lupu, Untangling the Strands of the Fourteenth Amendment, $77 \mathrm{MICH}$. L. REv. 981, 1019 (1979).

69. See Government by Cliche, supra note 22, at $390-92$. This article contains Chief Justice Rehnquist's ultimate anti-natural rights statement. If seventy percent of the American people wish to remove the Bill of Rights from the Constitution, then according to our theory of constitutionalism, this would not be "an illegal, an immoral, 
view was not the Framers' view. The Framers viewed majorities, even massive majorities, as inherently limited in wielding power.

Moreover, while the Justices may each act alone, the Court acts corporately. It is never going to be easy to convince five Justices, appointed through the political process, to condemn a generally accepted practice without the comfort of strong textual support. If even without textual support, a majority of the Court finds a practice repugnant to conscience, we can have some confidence in their conclusions. They are practicing the tradition of inherent rights that Professor Jaffa supports. When a judicial majority does this, Professor Jaffa should condemn them for being wrong, for being unpersuasive in their reason, or for giving no reasons at all. There have been occasions on which the Justices have been wrong, unpersuasive, and willful. But one who believes what Professor Jaffa believes should not condemn the Justices for standing against injustice.

I agree with Professor Jaffa that liberals do not follow the tradition of the Declaration of Independence. In the portions of opinions by Justice Brennan quoted by Professor Jaffa, the plea is made to a future consensus. That is, Justice Brennan asserts that one day a majority will agree with him in condemning the death penalty. If this assertion were merely prediction, we could say that truth is powerful and is eventually irresistible. But Justice Brennan is justifying, not predicting. He votes against the death penalty in part on the strength of a future majority. Justice Brennan emerges in Professor Jaffa's quotations as devoted to a sociological jurisprudence similar to that of Chief Justice Rehnquist. Both Justices rely on notions of majority consensus. Chief Justice Rehnquist relies on today's majority; Justice Brennan relies on that of tomorrow. Neither man relies on an enduring standard of right.

Professor Jaffa thus shows us an exhausted constitutional tradition, not so much at the level of what judges still do, but what legal thinkers teach about the possibility of a moral law. This exhausted tradition is incapable of addressing the serious issues of the rights of persons and of the nature of free government for it lacks faith that people have such rights or that free government is inherently superior to any other kind. On the

or an improper act." Chief Justice Rehnquist added, "[i]t might well be unwise . . ." Yes, it might. 
conservative side, the tradition drifts toward utilitarian tinkering, ${ }^{70}$ on the liberal side, toward alienated individualism. The traditional mainline thinkers fail to ask of law any questions larger than itself.

We are not destined, doomed I should say, to continue on this course. Professor Jaffa has put us in touch in a vital way with a tradition of law much healthier than the one we know today. But Professor Jaffa is not content to let that tradition speak to us. He is justly proud, but at the same time fearful, because the Framers' power may be misread and misused.

From his perspective, Professor Jaffa's fear is well justified. Once we take the rights of persons seriously and the strengthening of free government as law's obligation, we cannot avoid asking about the rest of the rights of man: about economic rights - to shelter, food, clothing, and education; about social rights-to wear religious clothing and to love a person of the same sex; and about corporate rights-to prevent the police from lying to attorneys and to bar unconstitutional actions by our government. The Supreme Court has spoken negatively on all of these matters. In each case, Professor Jaffa seems confident that we have been faithful to the Declaration of Independence. I am certain we have not. But it is clear to both of us that we must strive within our powers to be faithful. For our legal tradition and those who participate in it are judged by enduring standards of right and wrong.

70. There is nothing hateful about "utilitarian tinkering." If law and economics can help to prevent accidents at lower cost, to better deter crime, or to recognize inconsistencies between goals and means, why would anyone object? It is only the imperial claim to embody all clear-thinking human understanding that makes law and economics a proper object of scorn. 